\title{
Use of Cymelarsan in Goats Chronically Infected with Trypanosoma evansi
}

\author{
C. Gutierrez, ${ }^{a}$ J. A. Gorbera, ${ }^{a}$ K. Bayou, ${ }^{b}$ and F. van Gool ${ }^{c}$ \\ ${ }^{a}$ Veterinary Faculty, University of Las Palmas, 35416, Las Palmas, Canary Islands, Spain \\ ${ }^{b}$ Faculty of Veterinary Medicine, Addis Ababa University, Debre Zeit, Ethiopia \\ ${ }^{c}$ Merial, Lyon, France
}

\begin{abstract}
Toxicity and therapeutic trials using Cymelarsan (an arsenical compound) against Trypanosoma evansi infection were carried out using chronically infected goats. For the toxicity trial, 40 goats were divided into four groups of 10 animals each; the first three groups received s.c. injections of 5,10 , and $15 \mathrm{mg} / \mathrm{kg}$ bw of Cymelarsan, respectively, and the last one served as control. No systemic reaction was observed in any goat throughout the experiment. For the therapeutic trial, 15 adult female goats were inoculated intravenously with at least $1 \times 10^{5} \mathrm{~T}$. evansi isolated in the Canary Islands. Six months after inoculation, the animals were treated with Cymelarsan at single dose of $0.3 \mathrm{mg} / \mathrm{kg}$ ( 5 animals), $0.5 \mathrm{mg} / \mathrm{kg}$ ( 5 animals), and $0.625 \mathrm{mg} / \mathrm{kg}$ (5 animals). At 4 and 6 weeks after treatment, two goats belonging to $0.3 \mathrm{mg} / \mathrm{kg}$ group showed recurrence of trypanosomes. Parasitemia, however, was negative in all animals belonging to 0.5 and $0.625 \mathrm{mg} / \mathrm{kg}$ groups until the end of the experiment $(6$ months after treatment). Thus, it can be concluded that Cymelarsan is a safe trypanocidal drug for goats and that the curative dose is $0.5 \mathrm{mg} / \mathrm{kg}$ or above.
\end{abstract}

Key words: Trypanosoma evansi; goats; Cymelarsan; arsenical compound

\section{Introduction}

Since its introduction in 1921, suramin $\left(\right.$ Naganol $^{\circledR}$; Bayer, Leverkusen, Germany) was the main therapeutic drug for Trypanosoma evansi infection (surra) in susceptible animal hosts. However, massive use led to the emergence of suramin-resistant T. evansi populations in many parts of the world. Cymelarsan ${ }^{\circledR}$, an arsenical compound (Merial, Lyon, France), is the newest trypanocidal drug marketed and it has proved to be effective in mice against $T$. evansi strains resistant to suramin or quinapiramin sulfate. ${ }^{1}$ Cymelarsan is currently used against $T$. evansi infection in camels, ${ }^{2}$ cattle, ${ }^{3}$ and horses. ${ }^{4}$ However, there is only little information about the use of Cymelarsan in other susceptible animal species, like pigs or small ruminants. With re-

Address for correspondence: Carlos Gutierrez, Veterinary Faculty, University of Las Palmas, 35416, Las Palmas, Canary Islands, Spain. Voice: 34-928-4521115; fax: 34-928-451142. cgutierrez@dpat.ulpgc.es spect to small ruminants, there is only one report of the use of Cymelarsan in inoculated goats using T. evansi CP 582 strain isolated in Kenya in $1981 .{ }^{5}$ On the other hand, toxicity profiles of Cymelarsan in goats have not been performed until now; thus, possible toxic consequences of the use of Cymelarsan in goats are unknown.

Goats could play an important role in the dissemination of T. evansi infection in tropical and subtropical areas. Consequently, toxicity and therapeutic profiles were carried out in this work using goats chronically infected by T. evansi.

\section{Materials and Methods}

\section{Toxicity Profiles}

Forty female Ethiopian goats were used for this experiment. Thirty goats were divided into 
three groups of 10 animals each. Cymelarsan was administered subcutaneously in each group at a dose of 5,10 and $15 \mathrm{mg} / \mathrm{kg}$ bw, respectively. The other 10 animals served as control.

\section{Experimental Infection}

Fifteen adult female goats were inoculated intravenously with at least $1 \times 10^{5}$ T. evansi isolated from a dromedary camel in the Canary Islands. The animals were housed in fly-proofs pens in the experimental inoculation area at the University of Las Palmas. Six months after inoculation the goats were treated intramuscularly with Cymelarsan at a single dose of $0.3 \mathrm{mg} / \mathrm{kg}$ (5 animals), $0.5 \mathrm{mg} / \mathrm{kg}$ (5 animals), and $0.625 \mathrm{mg} / \mathrm{kg}$ (5 animals). The animals were examined every 2 weeks by parasitologic (Woo technique; two tubes per animal) ${ }^{6}$ and serologic (CATT/ T. evansi; Institute of Tropical Medicine, Antwerp, Belgium) procedures for 6 months.

\section{Results}

\section{Toxicity Profiles}

No systemic reaction was observed in any goat injected with Cymelarsan at different doses. However, a local swelling at the inoculation point was detected in the animals. This reaction disappeared within a few days after inoculation.

\section{Experimental Infection}

The animals showed a subclinical course of infection and parasitemia remained low but persistent throughout the experiment. Only carpal arthritis was observed in one goat at 5 months post inoculation. After treatment, all animals were negative from the first check-up (at $24 \mathrm{~h}$ post treatment). At 4 and 6 weeks after treatment, two goats belonging to the $0.3 \mathrm{mg} / \mathrm{kg}$ group showed recurrence of trypanosomes. However, all animals belonging to the 0.5 and $0.625 \mathrm{mg} / \mathrm{kg}$ groups were negative for parasitemia to the end of the experiment (6 months after treatment). Serologically, however, all animals remained positive until the end of the experiment, although agglutinations were weaker from 5 months after treatment in some goats belonging to 0.5 and $0.625 \mathrm{mg} / \mathrm{kg}$ groups.

\section{Discussion}

The toxicity trial showed no signs of acute toxicity in any goat at dose of 10,20 and 30 times the medium dose used in this study $(0.5 \mathrm{mg} / \mathrm{kg})$. This would demonstrate that Cymelarsan can be considered safe for goats.

On the other hand, the results obtained in this study seem to confirm the efficacy of Cymelarsan for the treatment of T. evansi in goats. At $24 \mathrm{~h}$ post treatment, the parasites were eliminated from the bloodstream, and relapses were only detected in animals belonging to the $0.3 \mathrm{mg} / \mathrm{kg}$ group. Cymelarsan is recommended in camels and horses to treat T. evansi infection at $0.25 \mathrm{mg} / \mathrm{kg}$ of body weight. However, that dose has not been curative for goats. In a previous trial using goats experimentally infected with T. evansi CP 582 strain, curative dose were $0.3 \mathrm{mg} / \mathrm{kg}$ and $0.625 \mathrm{mg} / \mathrm{kg}$ for acutely and chronically infected animals, respectively. ${ }^{5}$ However, trypanosomes were demonstrated in cerebrospinal fluid (C.SF) in two chronically inoculated goats. Relapses are common in late treatment with trypanocidal drugs, and are usually due to extravascular trypanosomes beyond the reach of the drug. These trypanosomes reinvade the blood once the circulating drugs fall below effective levels. ${ }^{7}$ CSF was not investigated in our experiment, but all animals were negative for parasitemia for almost 1 year after treatment. On the basis of our results, a dose of $0.5 \mathrm{mg} / \mathrm{kg}$ could also be curative for chronically infected goats, although further studies are necessary using a larger number of animals and different T. evansi strains. This finding can be important because goats normally show a subclinical picture of the disease, and the chronic 
infection is the most likely form seen in field conditions. ${ }^{8}$

\section{Conflicts of Interest}

The authors declare no conflicts of interest.

\section{References}

1. Zweygarth, E. \& R. Kaminsky. 1990. Evaluation of an arsenical compound (RM 110, mel Ct, Cymelarsan ${ }^{\circledR}$ ) against susceptible and drug-resistant Trypanosoma brucei and T. b. evansi. Trop. Med. Parasitol. 41: 208-217.

2. Musa, M.M., A.M. Abdoon, B.T. Nasir, et al. 1994. Efficacy of Cymelarsan in the treatment of natural chronic Trypanosoma evansi infection in camels in the Sudan. Rev. Elev. Med. Vet. Pays Trop. 47: 397400.

3. Payne, R.C., I.P. Sukanto, S. Partoutomo et al. 1994. Efficacy of cymelarsan in Friesian Holstein calves in- fected with Trypanosoma evansi. Trop. Anim. Health Prod. 26: $219-226$.

4. Murilla, G.A., R.E. Mdachi \& J.K. Kagira. 2005. Evaluation on the local tolerance and efficacy of melarsan oxide cysteamine (Melcy, Cymelarsan) in horses. Minutes of the 26th Annual Meeting of the OIE ad hoc group on Non Tsetse Transmitted Animal Trypanosomosis, Paris, 22 May 2005.

5. Zweygarth, E., J. Ngeranwa \& R. Kaminsky. 1992. Preliminary observations on the efficacy of mel Cy (Cymelarsan) in domestic animals infected with stocks of Trypanosoma brucei brucei and T. b. evansi. Trop. Med. Parasitol. 43: 226-228.

6. Woo, P.T.K. 1969. The haematocrit centrifuge for the detection of trypanosomes in blood. Can. F. Zool. 47: 921-923.

7. Stephen, L.E. 1986. Trypanosomiasis: A Veterinary Perspective. pp. 449-450. Pergamon Press, Oxford.

8. Gutierrez, C., J.A. Corbera, M. Morales, et al. 2006. Trypanosomosis in goats. Current status. Ann. N. Y. Acad. Sci. 1081: 300-310. 